\title{
Islamic Economics and Modern Economies: Resetting the Research Agenda
}

\section{Suleiman Ibrahim Cohen*}

Department of General Economics, Erasmus School of Economics, Erasmus University Rotterdam, Rotterdam, The Netherlands

*Corresponding author: Cohen SI, Department of Economics, Erasmus School of Economics, Erasmus University Rotterdam, P. Box, 1738, 3000 DR Rotterdam, Rotterdam, The Netherlands, Tel: +31104082902; E-mail: cohen@ese.eur.nl

Received date: March 24, 2017, Accepted date: April 25, 2017, Published date: May 02, 2017

Copyright: (c) 2017 Cohen SI. This is an open-access article distributed under the terms of the Creative Commons Attribution License, which permits unrestricted use, distribution, and reproduction in any medium, provided the original author and source are credited.

\begin{abstract}
The paper serves as background material for the review of debated issues and standpoints in the theory and application of Islamic economics, IE; and for discussion of fruitful research avenues in application of IE to modern economies. The focus is on six areas: (1) theory: links between IE and mainstream economics; while topics (2) to (6) treat applications of the given directives in Islamic economics: (2) replacement of riba by Islamic banking and financial products, (3) replacement of gharar by Islamic insurance and risk management, (4) substitution of haram by Islamic merits, (5) Waqf, and (6) Zakat. The paper proposes some twenty topics of mainly applied research making use of various research methods.
\end{abstract}

Keywords: Islamic economics; Islamic banking; Economy

\section{Introduction}

\section{Focus}

Quran and Sunnah, in common with other religious texts, contain statements on wide ranges of behavioural misconduct and remedial directives. However, Quran and Sunnah differ from other religious texts by the significant attention given to payment transactions with undesirable outcomes, and by issuing directives to combat them. The undesirable outcomes are not only limited to the world one lives in but also to the hereafter ${ }^{1}$.

Islamic economics, IE, which is, Fiqh al-mu'amalat, literally means the science of transactions. IE focuses thus on agent transactions; in particular, problematic transactions with undesirable outcomes; and on favourable transactions with desirable outcomes; and by extension, IE formulates directives to avoid the undesirable and promote the favourable.

As such, it is readily seen and acknowledged that there are five categories of economic transactions and directives in IE: three are prohibitions and two are obligations ${ }^{2}$. These are:

- Prohibition of borrowing and lending transactions containing payments of interest, riba.
- Prohibition of transactions involving excessive uncertainty, risk, asymmetric information, moral hazard, gharar.

- Prohibition of consumption and production of liquor, pork, and other demerit goods, haram.

- Trusts returns from common property to serve for the benefit of community, Waqf .

- Charity contributions by the more endowed to serve for the benefit of the least endowed, Zakat ${ }^{3}$.

Compliance with the five IE directives in past and contemporary Islamic economies has led to the establishment of important institutions that bolster these directives, such as Islamic banking with diversified products that evade interest payments, thus avoiding riba ${ }^{4}$ gharar; regulation of prohibited consumptions, productions and investments, in short, demerit goods or haram (and by analogy promotion of Islam blessed goods, in short, merit goods or halal); establishment of common property trusts whose proceeds can be used for provision of public goods among others, Waqf , and of charity contributions as a means of endowment redistribution, Zakat. The five economic directives, their institutional realization in contemporary economies, and in particular research endeavours aimed at supporting and perfecting these institutional realizations in the rapidly modernizing contemporary economies, are the focus of the paper.

It is argued by some that the five directives are godly revelations, and do not belong to the realm of theory analysis and policy making. But these directives have been adopted by Islamic economics as the

1 In Islam, as in many religions, the rewards and punishments that one expects to receive for one's deeds on earth, in the hereafter, may greatly influence the agent's behavior in economic and non-economic matters. The gains and losses believed to accrue in the hereafter can have higher weights than gains and losses in the real world one lives in; and thus the hereafter can dominate the attitude towards specific economic transactions. For instance, for the strict Islamic believer paying or receiving interest is considered an act that would deduct from a person's goodwill in the hereafter and make that person worse off in the hereafter.

2 It is noted that these five directives/institutions relate to Islamic economics and the functioning of the Islamic economy and are separate from the five fundamental pillars of Islam, even though zakat belongs to both.

3 Zakat is viewed as obligatory by Sunnis, and as voluntary by Shias.

4 Islamic banking abstains from using the word interest or Riba. But it does not mean that the deals are interest free. Interest payments take the form of profit, dividend or hiring rates for the lender and handling costs, repayments or rent for the borrower. 
cornerstones of the sub-discipline, and as such they form together the crux of IE theory and policy. Hence, IE theory, just like any social science theory, is subject to checks of consistency and realism. Related to this is the fact that godly revelations can be interpreted differently in different settings. Islam, in similarity with other religions, is a religion with many diverse followings and principals. Islam cannot be assumed to be constant or static over space and time. The Shia and Sunni, are only two distinctly known Islamic belief systems. The degree of halal and haram, vary among the believers and could also vary over time. Similarly, the scope of Waqf and Zakat obligations is elastic. This complexity further increases when sub-sects of Sunnis and Shias, e.g., the Wahabis, Salafees, Esna-asharis, Fatamiees, etc., enter the picture. Therefore, while general agreement on basic results in IE is reachable, obtaining full consensus on refined analytical results of treated aspects in IE may not be always feasible.

It is noted also that Quran and Sunnah include other directives on non-transactional behaviour that may affect the economy indirectly, i.e., Islamic inheritance laws, property protection, etc. For the purpose of the paper, some boundaries for the scope of IE have to be fixed, so these topics are for the moment considered to be outside the immediate scope of IE. These topics are also among the least discussed in $\mathrm{IE}^{5}$. With these qualifications in mind, the paper will focus on a basic analysis of the five IE directives.

\section{Background}

IE literature provides elaborate historical accounts of the ups and downs in development in thoughts and implementation of IE [1] ${ }^{6}$. Thoughts and applications ran high in the glory period between 800 and 1200, and both retarded after 1200. The advance in IE thought reached its climax with Ibn Khaldoun in the 14th century, in his holistic analysis of the Islamic society as a socio-political-economic system that is guided by Islamic ethics. Regarding the actual implementation of IE, historical records for the glory period point to activations of the prohibition of riba, gharar, and haram consumptions, and of the institutions of Waqf and zakat. Next to social control, the administrative control function was vested in Hisba, which was the regulatory institution that saw to it that the economic directives were observed, among other directives of a non-economic nature. But there is no way of tracing back the degree of violations of the prohibitions and obligations. From 1200 and onwards until recently, both IE thought and implementation weaned over time as national sovereignty was undermined by world events occurring one after another, and as Arab regional leadership gave way to Europe. Economic systems in most developing countries started reflecting the impacts of the colonial rule, the industrial revolution, the free markets, and the state management of economic development policies.

Two important signals of renaissance in IE came up in the 1970s. One important event is the Islamic revolution of 1979 in Iran. In the process of reforming the Iranian economy new dimensions were introduced in the debate on Islamic economics. Viewpoints were put forward that can be named for short the principled standpoint: IE and mainstream economics (also called conventional economics) are two disciplines on academically equal feet; and the two disciplines represent two competing economic systems, one guided by ethical and social principles and the other guided by materialist and individualistic preferences. The principled standpoint supported a research agenda on IE that would apply the tenets of, Islam to extend IE far beyond the directives of IE proper, towards an all-inclusive economic system. For some advocates this meant formalization of a new and comprehensive discipline of IE as an alternative to contemporary economics. Various conferences, original research, and doctorate theses to that end took place in the next decades. Most output was motivated by worthy intensions but the research agenda to redo economics from square one did not catch steam.

The other important event occurred three years earlier in 1976, with the convening of the first international conference on IE in King Abdul Aziz University, Saudi Arabia. The conference reopened the debate on principles and applications of IE in Islamic countries. The Saudi conference was followed by more conferences in other Islamic countries, hosted by the International Association of Islamic Economics in collaboration with the Islamic Development Bank. The focus of the conferences gradually shifted towards application of Islamic banking. Although these conference contained scholarly papers that posed IE as a substitute discipline for mainstream economics along the principled standpoint of the previous paragraph, most contributions represented a flexible standpoint that viewed the Islamic economy as adding filters to the market economy, and the Islamic economics as enriching mainstream economics with own cases and experiences, and in no way seeking discipline replacements. In its study and selection of banking products that are Sharia compliant, the flexible approach introduces compliance filters, and selects/modifies outcomes accordingly. This can be called the flexible standpoint of IE, in contrast to the principled standpoint discussed earlier.

From the 1980s onwards serious and extensive institutional applications of IE in finance and insurance showed up in many Islamic countries. In the last two decades, especially after the financial crises of 2007-08, Islamic banking (IB) spread to non-Islamic countries as well, partly due to the less risky character of IB and partly due to an autonomous demand for Sharia compliant IB. This has been accompanied by a surge in world conferences on and involvement of international economic organizations in IE, and an increasing number of universities and institutes that offer specialized training in Islamic banking and insurance, and that advance theoretical and empirical research in IE. Islamic entrepreneurship has made great leaps in the past decade, whether it is in the area of Islamic banking, finance, insurance, or in the production and consumption of goods and services that associate and comply with Islamic norms and images.

A study of developments in IE that occurred in the last two decades, points to two tendencies with significant consequences for the future research agenda in IE. First, the theoretical and policy interpretations of IE along the principled and the flexible approaches show significant differences in research strategies, mediums and outcomes. The principled is deductive and abstractive. The flexible is inductive and empiricist. The debate between the two approaches concerning

5 The Islamic inheritance laws, IHL, involves payment transactions and as such some analysts may count IHL as a sixth IE directive. IHL impose upon the heirs that their share of the inheritance be distributed in monetary terms. Accordingly, inherited assets are to be sold in order to divide the inheritance on heirs. Implementation of IHL has prevented the growth of family owned large businesses in Islamic countries, in contrast to their abundance in other countries. Observance of IHL tend to be diluted by the setting up of trust funds in the form of waqf with family relatives as beneficiaries.

6 For instance, Elashker and Wilson (2006). 
outcomes is still uncompromising and lively. However, a quick examination of more recent refereed articles shows a greater turnover for the flexible than the principled approach, which has its implications for future research. The unresolved controversies between the two approaches on the objectives and scope of IE suggest that there may be ground for pursuing alternative approaches in future research. The paper will elaborate on alternative approaches.

Second, there is increasingly more research attention going to the promotion and marketing of Islamic banking products and to Islamic blessed goods and services, in short, merit goods. Islamic entrepreneurship is the vehicle for realizing enormous economies of scale and scope in this area. Given the Islamic market with its population size, purchasing power and the wide range of goods and services that associate with Islamic based consumer preferences, Islamic business is on the verge of entering vast economies of scale and scope. This will have a lasting effect on the research agenda of IE. Islamic entrepreneurships take often the form of ambitious private public partnerships in which big business and nation states cooperate across Islamic countries with participations from rest of the world. This development can be viewed as a shift from academic discussions of IE to operational studies for business applications that associate with Islam blessed merit goods. The research output in this area is intended to service Islamic business firms and partnering nation-states in joint ventures that target a very rapidly expanding Islamic market for Islamic merits. A generally recognized problem with most commissioned business research is that such research is often directed to answer raised questions of the one user, i.e., the business concerned. It often happens that moderate extensions and/or refinements of the scope of such IE business studies so as to consider economy wide aspects contribute to raising the academic level of the research program and to producing valuable findings for more users. There is an obvious need to integrate academic with operational interests in this rapidly growing area of IE inspired business studies. The paper will address this need as well.

The objective of this paper is to serve as background material for the discussion of fruitful research avenues in IE regarding theory and application of the five IE directives. It is also pragmatic to consider the two tendencies stated above in resetting the IE research agenda. The paper is accordingly divided further into three sections. Section 3 will discuss the theory and analysis of the IE directives in relation to mainstream economics and comment on research prospects. Section 4 examines the actual institutionalization of the IE directives in contemporary economies, assess raised questions, and addresses research needs for operational adjustments, improved performance and overall impact. Section 5 gives a summary list of research topics ${ }^{7}$.

\section{Alternative Research Strategies in Linking Islamic Economics and Mainstream Economics}

What is the assessment regarding the IE principled and IE flexible research strategies? [2-4 $]^{8}$ And are there alternative research strategies? The principled approach is deductive in method; it starts on top with an abstract set of ideal norms and proceeds downwards in shaping a blueprint of how the real world should look like. No blueprint has been produced so far because the problem is underdetermined. The number of unknown variables to be determined enormously exceeds the number of postulated relationships. The approach is not fully supported by some religious scholars who view the revelation objectives (Makasid) as moral and societal, and see them undergoing estrangement if they were misinterpreted as a reference book for constructing a model of the economy or an economics textbook. The approach has been criticized on other grounds [5] $]^{9}$ In contrast, the flexible approach is inductive in method, and is in some sense doing the opposite as it starts from empirics and moves upwards towards abstracted ideals. In its study, selection and design of banking products that are Sharia compliant, the flexible approach introduces compliance filters, chooses and modifies outcomes accordingly. While all countries of the world have filters reflecting their specific preferences, the difference in the case of IE lays with the relatively more coherent set of filters as explicated in Islamic revelations. Research along this line has been more contributing, pragmatic and empiricist. But this approach is criticised as well: among other criticisms, the inductive research can get overwhelmed by the investigated details and statistics, to the extent that it may loose track of the revelation objectives behind IE, and end up in cosmetic results $[6]^{10}$.

Shortcomings of the deductive and inductive research strategies in IE suggest a need for alternative research strategies. One promising alternative is the abductive research strategy. The inclination of abductive research is phased, economical and pragmatic: (a) it tries to explain a new phenomenon in terms of the simplest acknowledged theory and/or facts, (b) it passes the explanation through experimental testing, (c) if this works then that explanation is the best guess; (d) if it does not work, it goes to the next more complex grounded theories/ facts. Abductive reasoning is common use in artificial intelligence, but also in many of our daily consciously reached decisions as it yields the best guess with the information at hand. Abductive reasoning, which will be briefly introduced here, opens up many useful research areas. It is virtually absent in IE literature.

As stated earlier, IE has a relatively coherent set of filters with regard to prohibitions of riba, gharar, haram, and their replacement by counterpart remedial institutions, and with regard to the institutions of Waqf and Zakat. While it is commonly held that the five economic directives were guided by ethical values, in the abductive analysis these directives can be shown to be derivable from logical intercourse in

7 In this connection, mention can be made of the initiative of University of Dubai, UD, to build a viable PhD research program on theory and applications of IE in contemporary economies. The background notes and the listings of research avenues in this paper can serve as useful inputs for a UD conference on the topic in 25-6 November 2017, and the setting up of the research program. The paper serves also as conference paper for the International Conference on Applied Economics and Policy (ICAEP), University of Malaysia, Kuala Lumpur, 21-2 August 2017.

8 Hundreds of Islamic economists wrote in favour of the principled and of the flexible approaches, which makes it cumbersome to quote lengthy references. It suffices here to mention one recent example from each: for instance, Nomani and Rahnema (1992), and Chapra, M.U. (1996), respectively. There are also Islamic economists who took an intermediate standpoint, for example, Naqvi (1977).

9 Pryor (1985) described the principled approach as otherworldly in its attempt to reinvent wheels that have evolved throughout history for one and the same human race.

10 Cf. Khan (2013). 
mainstream economics, and in particular the use of microeconomic and welfare economics theory in highlighting market failures and remedial state interventions. We give below the mainstream economics version and follow next with the IE version and their mutual accommodation.

In mainstream economics we analytically distinguish between five types of underlying causes that result in market failures and featured manifestations ${ }^{11}$. Subsequently, market failures are confronted, corrected and reduced by institutional reforms and by state interventions. (A) Presence of indivisibilities in production and finance result in monopolistic practices. Ultimately, reforms in market institutions, state regulations or outright nationalization correct for the failure. (B) Presence of future uncertainties and asymmetric information leads to cloudy deals and hazardous governance. Here too, reforms in corporate governance and state regulations correct for the failure. (C) Negative externalities occur when some agents pursue demerit actions or self-enriching actions with greater detrimental side effects on others, that is social cost > private benefits. Conversely, positive externalities occur when agents would follow merit behaviours that make the whole better off. Hence, the call for state intervention to discourage consumption and production of demerit goods and encourage merit goods via taxes, subsidies, information and demonstration. In other contexts, the remedy to external effects of one party on another party is their internalized co-integration. (D) Markets fail to organize demand and supply of collective needs and the management of common property, hence the rationale for replacing market by state management and provision of public goods. (E) Finally, realized allocation of resources is optimal to the extent that the underlying distribution of endowments among the population is considered acceptable. When markets fail to generate acceptable distributions of endowments, states intervene and redistribute incomes $[7]^{12}$.

Empirically, any observed market failure and the applied remedial actions can contain elements from other market failures and from their applied remedies. For instance, commercial banks can misuse their client deposits to create financial indivisibilities, monopoly power and credit overexpansion leading to market failures as in (A); they may establish cloudy deals that associate with hazardous governance, leading to market failure (B); or they may engage in self-enriching activities with negative externalities, leading to market failure (C). The financial crises of 2007-08 is now seen to be the combination of failures in A, B and C. In response, state interventions pursued corrective policies in all three areas ${ }^{13}$.

The five IE directives and the above analytics of market failures will be shown to fit perfectly with each other. To start with the first IE directive, depositing and lending transactions involving interest payments, riba, which are prohibited and replaced in IE, can be viewed as a major cause of market failure as they allow the intermediary money dealer to handle money as a joint product that is obtained as deposit and is later re-lent in multiple rounds to borrowers at virtually the same time. The transactional indivisibilities that the money dealer creates gives the dealer undeserved financial market power and monopolistic benefits vis a vis both depositors and borrowers, and allows the dealer to grasp multiple rewards from one and the same money asset. The money dealer's ability to pool transactions, create indivisibility and entertain monopoly in open-ended renting transactions of money assets, justifies labelling money renting as an inherent cause of financial market failure, that is, cause $(A)^{14}$. Furthermore, the created market power can lure the money dealer to engage in cloudy deals that result in hazardous governance as typified by market failure (B), and in other self-enriching transactions at a greater social cost for all agents, resulting thus in negative externalities as typified by market failure (C).

The IE remedy to prohibition riba is Islamic banking (IB), which can be viewed as averting the market failure by denying interest payments to play its pivot role in the unification and clearance of financial transactions. IB replaces interest transactions by diversified and separated financial products ranging from full to partial for borrowers and depositors covering profit and loss sharing partnerships in full and in part (musharaka and mudaraba), products directed to borrowers such as leasing arrangements and lending contracts (ijara, and murabaha) and products directed for depositors: dividend bearing bonds, sukuk, and Sharia compliant mutual fund stocks which depositors can buy and sell directly or employing the bank as an investment management agent, wakala. For 2012, estimates ${ }^{15}$ show that IB products directed to borrowers formed $83 \%$ of all Sharia compliant assets in the Middle East. Sukuk bonds and mutual funds, which are directed to depositors and investors, accounted for $12 \%$ and $4 \%$, respectively. The remaining $1 \%$ of assets is held by Islamic insurance, takaful.

The rewards for the bank from borrower transactions take the form of a handling fee or an agreed upon share in the returns. The rewards for the bank in depositor transactions is a residual share of the returns after dividend payment in case of sukuk, or handling fee or shared returns in case of mutual funds. All IB products are subjected to compliance clearance from Sharia counselling boards. As IB make their deposit and lending operations disjointed and divisible, apply separated accounting and earmarked transactions; Islamic banking would in principle experience low degrees of freedom, have low lending to deposit ratios, be more liquid and less risky. In principle, IB would end up with limited market power and minimal monopolistic

11 Although we generally speak of market failures, the sounder term is system failures, since the causes of these failures are behavioural and technological, and would basically occur in all economic systems: market run as well as state run or otherwise. There also many instances of ill-conceived state interventions that led to market failures and system failures.

12 The distribution adjustment is known as the Second Theorem of welfare economics, cf. Cohen (2000).

13 Some of the state corrections may show up to be missteps in the longer run. This is the case when states intervened to save loss making enterprises that should have been allowed to go bankrupt.

14 Note that the analysis here lays more emphasis on the indivisible character of the exchange medium and the exchange intermediary (money and money dealer), and less emphasis on the price of the exchange (interest). In contrast, IE discussions have been more preoccupied with interest, which makes the analysis less farsighted. There are lengthy debates on whether IS prohibition should be limited to usury (i.e. exploitative high interest rates, which is the literal translation of riba), or should apply to all interest rates. Analytically, the market failure lies in the tacit power of money dealers to create financial indivisibilities and not in the particular height of the interest rate; hence the prohibition of riba can be argued to cover all interest payments.

15 Cf. PWC (2013). 
practices, and thus avoid market failures features in A, B and C, other things remaining the same. The actual operation of IB can deviate from this picture because of intervening factors; this is a different issue to be dealt with in the next section.

The second IE directive forbids binding transactions involving high uncertainty, excessive risk, asymmetric information, and cloudy deals, as they all associate with gharar. Transactions that fit in gharar would include speculation, hedging, futures, FOREX, and insurance. We include gambling in this category as well ${ }^{16}$. All these transactions are likely to result in moral hazard and non-transparent governance; hence, they constitute a market failure as typified in (B). Furthermore, self-enriching transactions facilitate the rise of negative externality effects and a widening of the gap between private benefits and social costs as typified in market failure (C). The IE remedy to market failure from gharar is to avoid such suspicious transactions, but such a prohibition would eliminate a significant chunk of financial dealings in the economy, some of which is productive and necessary. One exceptional uncertainty activity that is permitted in IE is the cooperatively run Islamic insurance, takaful. Analytically, the insurance need is reformulated as a collective need that can be cooperatively run and financed by the insured participants, whereby the net gains or losses after compensating damage costs are shared together. Cooperative insurance can be viewed as the communal governance response to the uncertainty market failure (B), but also as the internalization response to externality effects, as typified in market failure (C), as well as a voluntarily organized collective good when the market fails to provide it, as typified in market failure (D).

The third IE directive prohibits consumption and production of liquor, pork, among others that are considered as demerit goods, haram; these goods have negative externalities, as typified in market failure (C). By analogy there are recent tendencies in Islamic economies to introduce Islamic preferences in consumer spending that can be viewed as merit goods. While the notions of demerit and merit goods do not translate literally into haram and halal, they do coincide with each other analytically. All countries in the world categorize some goods and activities as merits and some others as demerits, and often there is cross-country convergence on what is merit and what is demerit. As such, from an analytical viewpoint, one can argue that the fourth IE directive is not particular for IE, and is analytically speaking less relevant. However, there is an exceptional consideration in IE that makes the distinction between merits and demerits commercially highly significant for Islamic economies. Mention was made of recent tendencies in Islamic economies to introduce Islamic preferences in consumer spending that can be viewed as merits. These range from living styles in food, clothing, housing and architecture that associate with Islamic culture, to recommendations for travel and visits to Islamic sites. The new packages of Islamic merits have significant consequences for the consumption and development patterns worldwide, and by implication the IE research agenda. This is evident given the current size of Islamic population at 1.86 billion out of a world total of 7.48 billion, and a projected growth above average, resulting in a rate of Islamic to non-Islamic population of 1:3.
The fourth IE directive establishes the institution of Waqf. Initially meant for common property (collectively owned by all), the institution applies also to private property that is donated and converted into common property. Returns from the common property are used to provide public goods for all. Waqf allocations fulfil the distinguishing features of public goods: non-rival and non-excludable. Private markets fail to exist for goods and services that are non-rival and nonexcludable, hence these goods are provided as public goods. Waqf is thus an IE remedy response to market failure as typified in (D). Furthermore, by using revenue proceeds from common property to finance the public goods, Waqf has the advantage of evading issues of tax incidence in state financing of public goods ${ }^{17}$.

Finally, there is the fifth IE directive of zakat, which recommends/ obliges the more endowed to pay a charity contribution based on net equity of the person over the whole year (which is equivalent to annual savings) for the benefit of the least endowed. The directive includes other charities similar to zakat ${ }^{18}$. Analytically, the charity obligation can be viewed as a socially desired merit good for alleviating poverty incidence, a situation of negative externalities that the market is not able to avoid. In general, charity contributions to alleviate poverty have always been commonplace in many societies in the world, and are seen as a merit good worldwide. However, the honoured position of Zakat in IE as one of the fundamental tenets of Islam to achieve justice, adl, elevates the rank of the Zakat directive to be the redistributive mechanism in line with corrective measures in (E). Analytically, if Zakat is no more but a charity meant to eliminate poverty among Muslims, then it would stop as an obligation once poverty among Muslims is eradicated. But Zakat transfer, being a permanent obligation, must have its rationale embedded in the correction of a skewed relative distribution of income and wealth. Zakat is thus best viewed as a progressive correction to a less desirable initial distribution of endowments, as typified in (E).

The analytical framework employed and the results obtained in this section can be tabulated as done in Table 1 . The vertical columns show how the economic order is managed in mainstream economics (ME). The horizontal rows show how the economic order is managed in IE. The two descriptions are diagonally linked and each of the five types of market failures in the modern economic system has its corresponding counterpart in IE. The analytical framework lies in the one to one interpretation of market failures and their remedies. While ME and IE are identical on the market failures, their reactions to remedies of these market failures are different. ME gives free hand to the market to develop alternative remedies (new finance products) but imposes regulations on them. IE in its early times has more or less simply prohibited the market failing transactions, and was not much responding in offering alternatives. IE in the last couple of decades has been more experimental with introducing remedies.

The diagonal entries show full correspondence between the IE economic directives and how mainstream economics views market failures and correcting remedies. The other entries show linkages between the directives (and failures). The approach employed here is

16 Prohibition of gambling (maysir, qumar) falls conceptually in the same broad category of treacherous ventures (gharar), and will be considered as such henceforth.

17 Although the scripture assigns revenues from waqf for the provision and servicing of public goods, in practise the list of beneficiaries from wagf is often extended to include family members and close relatives. Although disputable, well-off families may initiate Waqf arrangements to safeguard the household business and/or property from being sold and partitioned among the heirs after after death of the household head.; which is obligatory in Islamic inheritance laws.

18 Donations relating to zakat are ushr (a 10\% tax on harvests), and Sadaqat al-Fitr (dispersed at end of Ramadan) 
based on abductive reasoning. In contrast to the deductive and inductive reasoning that are typical of the principled and the flexible approaches mentioned earlier, the abductive analysis proves to bring relevant insight and promising research results.

What are the takeaways from this section regarding the IE agenda for theoretical research? First, recent trend in published research suggest that the principled research approach and topics appear to have given way to the flexible research and topics, which are there to continue. But the statement is not without qualifications. Paradoxically, the flexible approach may produce irrelevant and cosmetic results if the contents of these studies are not sufficiently principled and embedded in IE. The abductive approach introduced in this section is a promising research strategy in IE. It is most grounded in theory, experimental in track, and follows the surest way for obtaining viable results.

\begin{tabular}{|c|c|c|c|c|c|}
\hline $\begin{array}{l}\text { Managing the economic order in } \\
\text { mainstream economics [remedies]/ } \\
\text { Managing the economic order in } \\
\text { Islamic EConomics [remedies] }\end{array}$ & $\begin{array}{l}\text { A. Indivisibilities } \\
\rightarrow \text { Monopolistic practices } \\
\text { [state regulation] }\end{array}$ & $\begin{array}{l}\text { B. Uncertainty } \\
\rightarrow \text { Imperfect } \\
\text { governance } \\
\text { [state regulation] }\end{array}$ & $\begin{array}{l}\text { C. Externalities } \\
\rightarrow \text { Social loss }>\text { private } \\
\text { benefit [tax demerits } \\
\text { subsidy merits] }\end{array}$ & $\begin{array}{l}\text { D. Public } \\
\text { goods } \\
\text { [financed by } \\
\text { taxes and } \\
\text { users fees] }\end{array}$ & $\begin{array}{l}\text { E. Distribution } \\
\text { [progressive taxes } \\
\text { and } \quad \text { welfare } \\
\text { transfers] }\end{array}$ \\
\hline $\begin{array}{l}\text { Riba payments create indivisibilities, } \\
\text { unjustified monopoly powers for money } \\
\text { dealers, [Directives: no riba, establish } \\
\text { interest free banking] }\end{array}$ & $x$ & $x$ & $x$ & & \\
\hline $\begin{array}{l}\text { Gharar full of uncertainties, mis- } \\
\text { governance [Directives: no gharar, } \\
\text { establish cooperative insurance] }\end{array}$ & & $x$ & $x$ & & \\
\hline $\begin{array}{l}\text { Haram goods result in negative } \\
\text { externalities [Directives: no haram/ } \\
\text { demerits, promote instead } \\
\text { halal /merits with positive externalities] }\end{array}$ & & & $x$ & $x$ & \\
\hline $\begin{array}{l}\text { Issue of collective utilization of common } \\
\text { property and collective ownership } \\
\text { [Directive: Waqf, revenue proceeds as } \\
\text { public goods] }\end{array}$ & & & & $x$ & \\
\hline $\begin{array}{l}\text { Issue of unfair distribution of wellbeing, } \\
\text { endowments } \\
\text { [Directives: obligatory Zakat transfers } \\
\text { for needy] }\end{array}$ & & & & & $x$ \\
\hline
\end{tabular}

Table 1: On linking Islamic economics to mainstream economics.

Second, a deeper look into the guiding common core of the five directives in IE reveals that the IE solution to problematic transactions lies in separating specific transactions from each other, and often earmarking for specific transactions the specific means with specific ends. This is apparent in Islamic banking where accounts and accountability for depositing activities are separated from lending activities. In Islamic insurance (II) too, the account for premiums received less damages paid is separate from the assets and liabilities account of shareholders. Earmarking is also practiced in IB and II, and is the general rule in Waqf and Zakat. Separation and earmarking tend to occur more often in eastern societies. Pooling of transactions and unchained use of means to ends are more common in western societies. There are needs to survey thoroughly the separation and earmarking tendencies in IE and to assess their welfare effects on efficiency and equity, at both the theoretical and empirical levels ${ }^{19}$.

\section{The Islamic Economy in Contemporary Economies}

Before examining the actual working of the five directions in contemporary economies, that is, the actual Islamic economic institutions, it is helpful to sketch their positioning in the circular flow as a whole. Figure 1 is the simplest possible circular flow of a modern economy, consisting of households, business and government and the interactions between them in the markets for goods, labour and finance, in fiscal transfers and in their trade and financial relations with the Rest of the World. As can be seen the role and influence of actual Islamic economic institutions in the circular flow is very small, in spite of their substantive significance. For instance, worldwide financial assets held by IB are estimated to have grown from $\$ 1.22$ trillion in 2012 to $\$ 2.2$ in 2016 , a remarkable annual growth rate of $15 \%$; but they form only about $1 \%$ of total world financial assets. Due to the overwhelming size of the commercial segment in a contemporary economy and the magnitude and impact of interacting markets in the rest of world, Islamic banking is compelled to adapt to the surrounding market parameters, the alternative is not to exist. This is evident from quantitative studies in Islamic economies that show the height of bank handling fees to be nearly equivalent to the interest rate. This is not the case with the operation of the other four directives, which by their nature are loosely linked and less integrated in the

19 The efficiency effect is complex since separation and earmarking world reduce degrees of freedom and would limit the reallocation of resources towards higher efficiency and economic growth. At the same time, separation and earmarking reduce monopoly power and could reduce costs in the longer run. As for equity, looked at statically, this undergoes less change under separation and earmarking. 
circular flow, but these have also a very marginal significance in the circular flow. It was already pointed that Islamic banking, Islamic funds and sukuk bonds accounted for $99 \%$ of Sharia compliant assets in 2012, leaving only $1 \%$ for Islamic insurance assets. Data on assets or incomes held in Waqf and Zakat are not there but must be very marginal compared to Islamic banking.

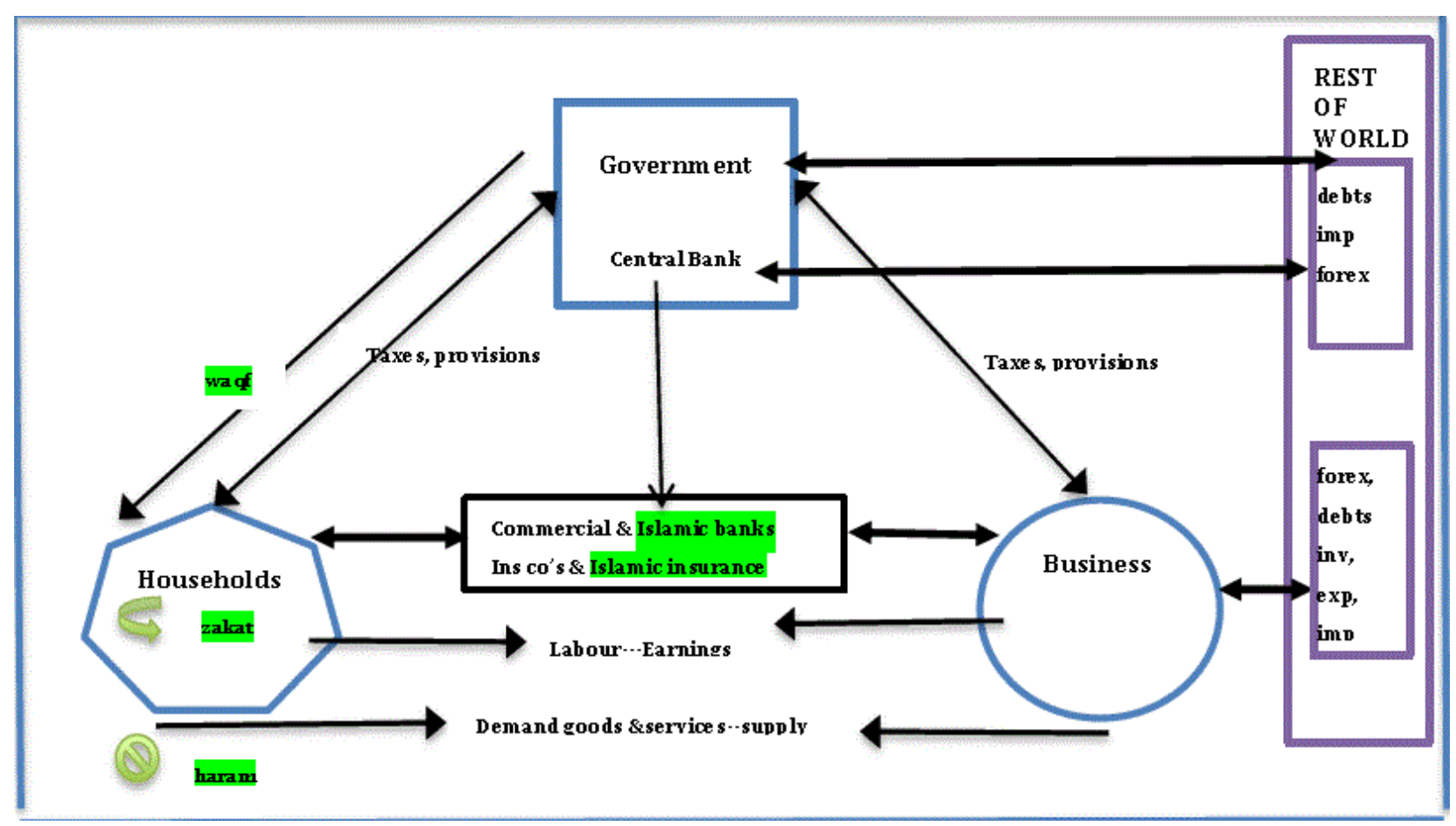

Figure 1: The Islamic economy in the circular flow.

\section{Islamic Banking}

Among the five IE directives, Islamic banking, IB, is most advanced in application, and in the generation of applied economic and business research. The IB economic research can be briefly grouped under IB products, IB sector performance, IB economy wide impact analysis, and IB country experiences. The IB business research relates to investment strategy, marketing, organization and management of IB nationwide and across nations.

IB started with replacing interest transactions by partnership contracts that were accredited as Sharia compliant. As partnership contracts turned to suffer from disputes on property rights and uncontrolled behaviour of principles and agents, IB turned to the selling of large varieties of investment products for depositors and lending contracts for borrowers at handling charges (see previous section). Research on financial products is dominated by the set of questions relating to genuine compliance to Sharia, reliable governance of issuers, riskiness and performance. The questions boil to assessing product confidence. Principled Islamic economists are the foremost opponents of IB products as they see most of the products as replications of conventional commercial debt instruments under Arabic names; while as can be expected, Islamic bankers support the flexible standpoint, defend the products they issue, and refer to a striking growth in the demand for their financial products of $15 \%$ per annum. On the face of it, and without further problem-solving research, both standpoints are legitimate and the questions remain unanswered. Ultimately, research on and applications of rating systems to IB products would enhance product confidence. A rating system needs to be preceded by standardization studies of the assessed products. The rating system can be subjectively based on opinions of experts and/or clients, but can also be objectively constructed as a rating index based on some aggregation of quantified confidence features of the products ${ }^{20}$.

The bottom line in assessing IB financial products is that whatever judgment is passed on IB financial products, the demand for them can count on huge numbers of customers with a preference taste for them. And suppliers of IB financial products, just like suppliers of other goods traded in markets, are better off when customers are attached to their brands of products/goods; and they are ready to spend much for marketing their products. In such a setting, it is important to make customers aware of the comparative utility of the offered IB financial products, and let them choose; and hence dissemination of information on applied ratings of competitive products is essential. More rigorous research on compliance with Sharia would require quantifying the Sharia objectives, Maqasid, in a measurable objectives function, and attach to this an economy model that traces the effects of the product on the objectives function. But this is not feasible, since the quantification of the objectives function may not be cleared by Sharia interpreters, Fiqh, and as no consensus may be reached on

20 Moody's, Fitch, S\&P, among others, are all rating IB and II companies. Less is done in terms of rating for their specific products, with the exception of Sukuks. 
specification of the relevant economy model. Hence, is the appeal of rating systems as a second best assessing medium.

Research at the sector level focused on comparative performance of IB versus commercial banking, $\mathrm{CB}$, and made use of a wide range of empirical methods varying from data envelopment analysis to econometric verification. There are findings showing that IB is more cost-effective than $\mathrm{CB}$ in a broad cross-country sample, but this finding reverses in the sample of countries where both IB and CB operate $[8,9]^{21}$. Besides, IB higher liquidity reserves explain the relatively better performance of Islamic banks during the financial crisis of 2007-08. However, when the whole period of 2006-11 is considered comparative performance reverses: Both indicators of return on equity and cost to income are found to be higher for IB than $\mathrm{CB}[10]^{22}$. There is thus a lot to be unravelled on comparative performance.

It was stated earlier that IB practices of avoiding indivisibility and separating accountability lead to reductions in the monopoly power of banks, their ability to inflate credit, and engage in hazardous uncertainties; these elements make IB more liquid, safer and stable which is an advantage in periods of financial vulnerability. The other side of the coin is that a too cautionary policy of IB (too low Lending to Deposit ratio, LTD) ignores a large segment of aspiring borrowers at tiny enterprises with little collateral. In this respect, an important research area lies in an earmarked expansion of LTD for exclusive lending to micro finance. The earmarking of the expanded lending facility to micro finance would relieve an unattended need with a high priority in IE, and add an IB product of significant importance.

At the economy wide level there has been less research on how the differentiated composition of the banking sector into IB and CB impacts the contemporary economy as a whole? As was stated earlier, the depositing and the borrowing functions are separated in IB from each other. This reduces functional indivisibility, market power, risky undertakings and financial volatility for the IB and for the economy as a whole. To the extent that less risk taking and restrained liquidity coincide with lower returns and growth, this will show up in the performance of the economy. There is thus a trade-off between caution and stability on the one hand and returns and growth on the other hand. This implies that while IB prioritizes stability over growth, CB chooses for growth over stability. The outcomes for the economy as a whole in terms of the above performance criteria depend on the IB and $\mathrm{CB}$ composition of the banking sector and their interactions. Note that the focus of the research here is not the performance of IB versus CB, but how the combination of IB and CB impacts welfare in the economy as a whole. The differential composition of the banking sector impacts the economy in other ways as well. While the fees paid by borrowers to the bank would tend towards equivalence in value to the average rent on similar loans in commercial banks they may not converge if the governance structures in IB and CB are not sufficiently transparent, and if the two branches in the financial market are not well integrated. Integration of IB and CB may face legal barriers as well due to the likelihood that Sharia law and commercial law may differ on questions of dispute resolution. The resulting financial market may best be described as a segregated or even a dual market due to differing systems of governance, which implies that the efficiency performance of the financial market, and the economy as a whole, is likely to be below the optimal for a fully integrated financial market. It will be instructive to quantify the efficiency loss from the segmented financial market for different countries and relate this loss to the achieved gains in stability. Because empirical data are the result of many intervening factors that are often difficult to identify, isolate and measure; formulation and application of simulation models are often more suited for tracing compositional and interactive effects of the banking sector on the growth and stability of the economy. The framework of computable general equilibrium models (CGE) is particularly relevant in this respect.

There is vast documentation of IB experience at the country level. Nevertheless, there are some unanswered questions at the country level. Although IB turnover in Islamic countries has been growing at an average of $15 \%$ pa, there are large variations between the countries in the annual growth that are not sufficiently studied and explained. Another area of inquiry is why specific countries have been more successful than others in introducing and leading particular IB products.

Finally, interest in IB has propelled a wide range of applied business research that investigates investment strategy, marketing, organization and management in (one user) specific contexts ${ }^{23}$. The challenge here is in designing the business research project in ways that substantiate links with economic theory and policy and in ways that make their findings more relevant to more users than the one user.

\section{Islamic insurance}

Synonyms that associate with the term gharar transactions connote a sense of unapproved dealings: uncertain, risky, adventurous, chancy, dangerous, jeopardous, treacherous, unsafe, crooked. Although there is no clear-cut absolute definition of the term and its scope in Sharia, yet the nature of gharar transactions implies a high likelihood of moral hazard and imperfect governance occurring. Hence, gharar is prohibited. One exception is cooperative Islamic insurance, takaful, where claims are paid from premiums and the residual is shared among policyholders, or accumulated for future claims, or a combination of both. Another exception is state sponsored life insurance and pension schemes, as moral hazard is assumed absent when the state is custodian.

Worldwide, risk management has become a very important research area given the scope of increasing risks with finance and globalization. Recent innovations in financial services have addressed risk management. In contrast, Islamic finance is severely constrained by its cautious attitude to risk management and risk insurance and the inability of Fiqh scholars to tame and adapt gharar transactions to the modern economy. The rejection of such financial products like hedging, options, derivatives, commodity and foreign exchange futures results in abstention from long term deals, and thus restricts Islamic

21 See Azam and Rettab (2016); and Beck, Demirgü, and Merrouche (2010)

22 PWC (2013) estimates for 2006-11 give ROE at 7.1\% for IB compared to $14.6 \%$ for CB; and CTI at $51 \%$ for IB compared to $39 \%$ for CB. The study suggests that greater customer centricity, operational efficiency and technological innovation are needed to lift financial performance of IB to the CB level.

23 For example the "World Finance and Banking Symposium" University of Dubai, Dubai, December 2016 included IB business research papers-in-progress on among others: Investment Strategy and Multiple Objectives Optimization in Islamic Investment Portfolios, The Shifting Fortune of Financial Institutions' Opportunistic Strategies; Impact of Banking Regulation in Egypt. 
finance to short-term deals, (even highly desired student loans, that are to be paid back years later after graduation, would not qualify under strict interpretations of the gharar restriction).

Is there space for compromising? Hedging contracts, by initiating and apprehending counter and/or complementary price movements, are a natural response to protect against financial loss in a risky world. To accommodate for gharar prohibition hedge insurance can be viewed as a collective good and be designed as such that beneficiaries can be called upon to cooperate in its provision, and share its outcomes cooperatively; but specialist bankers have to organize its management. This is more or less the way ahead. There is already trade in several collectively set Islamic forwards and Islamic hedging funds, but the scope is limited. For some IE scholars the weakness of Islamic economics in modern times emanates from its inability to enter into research on adaptive designs of controversial transactions $[11]^{24}$.

\section{Islamic merits}

In IE some specific goods are perceived as merit (demerit) goods, and thus private and state institutions are encouraged to promote (discourage) these goods along the perceived consumption preferences. If demerits are dropped out from the consumption package, this opens the way for their replacement eventually by merit goods, but not necessarily. Replacement by other neutral consumption goods is also possible. In IE, the percentage of demerit goods that are prohibited (alcohol, drugs, pork, armaments, casinos and the like) in total consumption is very small, by consumption norms elsewhere. Even if this percentage amounts to $3 \%$ to $5 \%$, it is attractive enough for suppliers of merit and neutral goods to compete for this market share. Merit goods that associate with Islamic culture are better positioned than neutral goods in claiming this $3 \%$ to $5 \%$ share in consumption spending.

In Islamic settings, consumer tastes become more easily accommodated to newly introduced goods that associate with Islamic culture than in the case of neutral goods. In fact, perhaps the most significant driving factor for the growth of Islamic banking products is their association with Islamic norms and their accreditation as Sharia compliant, which elevates these IB products to the status of merit goods. In similar ways, many consumer goods and services can be modernized, redesigned, refined and transformed into Islamic merit goods that will have high demand in Islamic settings. Entrepreneurs, marketing and the retail business are aware of, and alert to, the opportunities. By way of an example, some countries in the Gulf Cooperation Council have recognized way ahead of other Islamic countries, the potential advantages of their geo-economic positioning in the Islamic world and have invested significantly in physical and human infrastructures so as to facilitate realization of newly introduced merit goods. Perhaps one of the best demonstrations of the future outlook for the Islamic merit goods scenario is the establishment of Dubai Islamic Economy Development Centre $(\text { DIEDC })^{25}$, which aims at positioning Dubai as the global capital of Islamic economic jurisprudence, culture, knowledge and tourism. DIEDC is mandated to develop legal and institutional infrastructures that accelerate the development of Dubai's Islamic economy across various sectors. The centre is empowered to support government and private sector Islamic economy initiatives within key sectors that include standardization and monitoring of Islamic banking products and their extension; development of control and audit systems for business enterprises active in Islamic settings; certification and production and trade of fully integrated halal goods (comprising food, cosmetics, pharmaceuticals, textiles, and leather goods); promotion of Islamic family tourism and heritage tourism packages; promotion of digitalized infrastructure and digitalized Islamic literature, Islamic art, fashion, clothing, knowledge and education. The ambitious plans of Dubai are likely to trigger comparable undertakings in a few more Islamic cities. These Islamic merit goods initiatives can count on significant economies of scope and scale that associate with the Islamic world. The above listing of intended activities implies a very ambitious future research agenda on merit goods that is likely to play a dominant role in reorienting research topics and methods in IE. Research interest is likely to shift from general economics to business studies with focus on feasibility studies, marketing, regulation, and management, and a substantive increase in multidisciplinary research.

Waqf: A recent survey of Waqf research is helpful in screening current research interest in Waqf $[12]^{26}$. The study summarizes statistical features of 100 journal publications on Waqf in national and international journals in the years from 2011 to 2015. Results show that the Waqf research is dominated by discussions on the property component of Waqf and less on the cash component of Waqf (62\% and $38 \%)$. As regards the studied topics, the management of Waqf is highest at $34 \%$ with diversified topics accounting for $64 \%$. The country study context is dominated by South East Asia accounting for $68 \%$ of the articles, while Islamic regions accounting for the remaining $32 \%$. Furthermore, the style followed was more descriptive $70 \%$ vs analytical $30 \%$. Method followed was more qualitative $85 \%$ vs quantitative $15 \%$. The survey does not touch on how Waqf benefits are distributed on housing, health, education, poor groups, and religious instances. The survey findings suggest that Waqf research is limited given its descriptive and qualitative orientation, concentration in one region, and fragmentation in the studied topics. The limited scope of Waqf research is partly due to the diminished role of Waqf as a public goods provider as state planning and agencies acquired the leading role in the provision of public goods in many Arab countries.

Notwithstanding, there are recent tendencies for the revival of Waqf, specially in South and South East Asia. Useful research on Waqf would require data surveys on the properties and functioning of Waqf instances, which is generally very scarce and unstandardized. The GPS field survey of Waqf properties in Meghalaya State, India, is one outstanding example of data standardization and collection, to be followed by data processing and analysis ${ }^{27}$. Such research projects are highly informative and can be easily replicated elsewhere.

Zakat: In the previous section it was stated that Zakat transfer, being a permanent obligation, must have its rationale embedded in a skewed relative distribution of income and wealth. The issue of whether Zakat should be on net wealth added over the year or on income after deductions (that is annual savings) is not an issue since savings=change in wealth. However, there is as yet little insight into the economic basis for fixing Zakat at specifically $2.5 \%$, then or today. Some light can be thrown on this issue by studying, modelling and

$\begin{array}{ll}24 & \text { Siddiqi (2006) } \\ 25 & \text { DIEDC at http://www.iedcdubai.ae. } \\ 26 & \text { Rusydiana and Al-Farisi (2016) } \\ 27 & \text { http://www.wakf.gov.in/mpr/WAMSI_MPR_JAN2016.pdf }\end{array}$


simulating what can be called an IE normal income distribution and its Gini coefficient as implied by Zakat at $2.5 \%$ of annual savings? Such research would produce an IE normal income distribution that can serve as baseline for empirical comparisons among contemporary economies. For a functional and beneficial institutionalization of Zakat in modern society more questions can be investigated, opening up a whole set of research topics. Four areas are mentioned below.

Is Zakat on households only or on business as well? It was surely only on households in the glory period. Today, states in most Sunni countries apply Zakat on business [13 $]^{28}$. This is understandable as the state can easily inn the tax at source from business, and it is more difficult to inn the tax at a later period from households. Nevertheless, the state's Zakat on business creates bias as it taxes income of business shareholders and excludes other types of income. The bias is nullified if households are also compelled by the state to pay Zakat on other forms of income; but this proves to be more difficult to apply. The levy may also look unfair if non-Muslim shareholders are exempted from the redistributive zakat, but it need not be since IE includes a similar redistributive tax for well-off non-Muslims, jizya. Nevertheless, the levy system becomes unnecessarily complicated in absence of uniformity. The issues of assuring consistency, uniformity and simplicity in applying Zakat are ripe for careful investigation.

As Zakat is for redistribution it must be in excess of the state direct taxes that are paid for funding state public goods and other governmental functions. So there is a state direct tax and a redistributive obligation zakat. The current information available in this area shows that there is no adherence to the distinction, as tax authorities in some countries rebate and/or allow business to deduct the paid Zakat from the state tax levies $[14]^{29}$. The rebate undermines the fiscal budget, and being selective in application, it has distortive effects on incentives and allocations. Research on positive and negative interactions between direct taxes and Zakat is a priority.

There is the high probability of easy riding and noncompliance when knowledge on the valued wealth is solely vested in its owner. Reported estimates of income and/or wealth at the household level, registered, digitalised, and eventually checked by the fiscal authority, as is the case in a modern economy, seem to be the only solution to an effective and fair implementation of direct taxes and a Zakat tax. Feasibility research on moving the fiscal system along modern tracks is another priority.

The other parts of the equation are the earmarked transfer of Zakat to the less privileged. Should it be done privately, via intermediary welfare trusts as in the case with Waqf transfers, or be managed and redistributed by state agencies? These are difficult questions requiring further research on effectiveness and feasibility. In case of private transfers there are enormous problems of verification of the transfer from giver/rich to receiver/poorest (are they poorest?), likely governance exploitation by the giver, and unhealthy explicated dependence relationship for the receiver, etc. Evaluative research can lead to refuting the private channel as non-operational; leaving welfare trusts and state agencies as alternative channels. But a fair redistribution of Zakat taxes on the many potential receivers requires centralized data and centralized implementation, which makes it inescapable to revert to the national fiscal authority.
Shared issues in Waqf and Zakat: In both institutions there are questions on the design and transparency of governance rules, i.e., whether the contributions of the donators are genuinely spent on the beneficiaries that the institutions are meant to serve, or are subject of manipulations, Effective answers to these questions would require passing legislations by which the intermediary institutions that manage Waqf and Zakat are obliged to issue annual reports of their activities and get these reports officially cleared by some accountant agency that would check on whether the donations are genuinely spent on the beneficiaries that the institutions are meant to serve. This would not solve the problems of ad hoc allotments and of free riding caused by beneficiaries who may target multiple instances of Waqf and Zakat. The alternative, mentioned earlier, seems to be in centralizing redistributive spending in one state agency that can draw and implement a well-thought and consistent allocation strategy of the proceeds from Waqf and Zakat. Research on the design, simulation, impact and stepwise feasibility of such schemes is challenging, inviting and needed.

Another set of questions raised is what can the two institutions do in the supply of credit to the poor and the un-bankable tiny enterprises (micro finance), given the fact that large portions of the donations are sometimes not spent and are held as reserves $[15]^{30}$. Some IE scholars have called for the agencies of Wagf and Zakat to engage directly in lending to micro finance. This will constitute a departure from the separation and earmarking principles in IE. An alternative can be found along designed schemes by which Waqf and Zakat instances would pass grants to Islamic banks that the later can lend as micro finance. Here too, research on the design, simulation, impact and stepwise feasibility of such schemes is challenging and inviting. By analogy, an architecture student can obtain his/her Phd degree for proving his ability to apply architectural principles in drawing innovative designs. Similarly, economically founded forward-looking schematic designs in search of effective institutional mixes in the receipt and dispersal of funds are degree worthy, and can be more useful than the study of a hypothesis made by some economist decades ago.

\section{Summary of research topics and conclusion}

The below gives a birds eye view of some twenty research topics mentioned in the paper.

\section{At the theoretical level}

Developing the abductive approach as a platform for linking IE with mainstream economics Separation and earmarking principles in IE: Definition, rationale, examples, impacts, evaluation.

\section{At the applied level}

\section{Islamic banking}

Product level: Development and application of IB product rating system based on opinions of experts and/or clients, and/or based on some aggregation of quantified confidence features of the products. In either case, IB products need to be standardized (see below)

Standardization and monitoring of Islamic banking products

\footnotetext{
28 Ismail, Tohorin, Ahmed (2013)

29 Bakar Rahman (2007).

$30 \quad$ Alpay and Haneef (2015).
} 
Sector level: Development and simulation of IB scheme for an earmarked expansion of LTD for exclusive lending to micro finance.

Economy level: Study of economy wide impact of the segregated financial market (IB vs. CB) on efficiency, stability, growth and equity performance. The framework of computable general equilibrium models (CGE) is particularly relevant in this respect.

Cross-country level: Explaining variance in the growth of IB across countries and why/how specific countries have been more successful than others in introducing and leading particular IB products. Business research-Designing business research projects in ways that substantiate links with economic theory and policy and in ways that make their findings more relevant to more users than the one user.

\section{Islamc insurance}

Cost benefit analysis to the Islamic economy of foregoing various forms of gharar -like transactions.

Designing risk management transactions that are cooperatively organized and are able to secure collective benefits from contraspeculative transactions, along the lines of Islamic insurance.

\section{Islamic merit goods}

Feasibility study of audit and control systems for business enterprises in Islamic countries.

Feasibility study of the certification, production and trade of fully integrated halal goods (comprising food, cosmetics, pharmaceuticals, textiles, and leather goods.

Design study of Islamic family and heritage tourism packages. Feasibility, marketing, management.

Design study of digitalized infrastructure for Islamic literature, Islamic art, knowledge and education; and of Islamic cultural traits and clothing fashion. Feasibility, marketing, management.

Waqf

Field surveys of Waqf wealth, innings and outgoings by locality, informative data, evaluations.

An applied integration strategy for coordinating Waqf and the state in the provision of public goods.

\section{Zakat}

Modelling and simulating an IE normal income distribution and its Gini coefficient as implied by Zakat at $2.5 \%$ of savings. Apply results as baseline for empirical comparisons among contemporary economies.
Research on positive and negative interactions between Zakat and direct taxes. Centralized policy strategies for assuring consistency, uniformity and simplicity in inning Zakat and direct taxes.

Research on centralized redistributive spending of Waqf and/or Zakat proceeds with one state agency that can draw and implement a well-thought and consistent allocation strategy of the proceeds. Design, simulation, impact and feasibility of the scheme.

Designed schemes by which Waqf and Zakat instances would pass grants to Islamic banks that the later can lend as micro finance. Simulation, impact and stepwise feasibility of such schemes.

\section{References}

1. Elashker A, Wilson R (2006) Islamic economics, a short history. Brill Publishing, Boston.

2. Chapra MU (1996) What is Islamic economics.

3. Naqvi SNHN (1977) Islamic System: fundamental issues. Islamic Studies.

4. Nomani F, Rahnema A (1992) Islamic economic systems, Zed books, London.

5. Pryor FL (1985) The Islamic Economic System. Journal of Comparative Economics 9: 197-223.

6. Khan MA (2013) What is wrong with Islamic economics. Edward Elgar Publishing, London.

7. Cohen SI (2000) Microeconomic Policy. Routledge, London.

8. Azam I, Rettab B (2016) Comparative Performance and Innovation: Conventional Versus Islamic Banks. World Finance and Banking Symposium, Dubai.

9. Beck T, Demirgü AK, Merrouche O (2010) Islamic vs. Conventional Banking Business Model, Efficiency and Stability. The World Bank.

10. PWC (2013) Islamic Finance: Creating value. Price. Waterhouse Cooper, London.

11. Siddiqi MN (2006) Islamic banking and finance in theory and practice: a survey of state of the art, in Islamic Economic Studies 13: 1-48.

12. Rusydiana AS, Al-Farisi S (2016) How far has our Waqf been researched? Jurnal Etikonomi 15: 1-12.

13. Ismail AG, Tohirin A, Ahmad MAJ (2013) Debate on Policy Issues in the Field of Zakat. IRTI Policy paper.

14. Bakar NBA, Rahman AR (2007) A Comparative Study of Zakah and Modern Taxation. Islamic Econ 20: 25-40.

15. Alpay S, Haneef MA (2015) Integration of Waqf and Islamic microfinance for poverty reduction:

Case studies of Malaysia, Indonesia and Bangladesh. International Islamic University Malaysia, Kuala Lumpur. 